\title{
EVALUATION OF VEGETATIVE PHENOLOGICAL STAGES IN A SPRUCE MONOCULTURE DEPENDING ON PARAMETERS OF THE ENVIRONMENT
}

\author{
E. Bednářová, L. Merklová
}

Received: June 29,2011

\begin{abstract}
BEDNÁŘOVÁ, E., MERKLOVÁ, L.: Evaluation of vegetative phenological stages in a spruce monoculture depending on parameters of the environment. Acta univ. agric. et silvic. Mendel. Brun., 2011, LIX, No. 6, pp. $31-36$

Vegetative phenological stages were evaluated in a spruce monoculture of the third age class in the region of the Drahanská vrchovina Upland. Methods of the ČHMÚ (Czech Hydro-Meteorological Office) were used. Temperature requirements of Norway spruce for the onset of particular phenological stages were evaluated on the basis of sums of air effective temperatures higher than 5 ${ }^{\circ} \mathrm{C}$ and at soil temperatures, values exceeding $1{ }^{\circ} \mathrm{C}$ were taken into account. In the paper, years 2005 to 2007 were evaluated. Results obtained were compared with long-term monitoring for the period 1991-2004. The onset and duration of phenological stages differed in particular years depending on the course of weather. Evaluation of the 17-year period shows that onsets of phenological stages in particular years differed markedly. An interval for the "onset of budbreak stage" was 13 days, at the "stage of 50\% foliation" 14 days, the "stage of $100 \%$ foliation" 17 days. At the stage "full foliation", the interval amounts to 33 days in the period 1991 to 2007. The start of budbreak and foliation is affected by air and soil temperatures, which was also proved by statistical evaluations. High dependence between the onset of budbreak and air temperatures is confirmed by statistically significant correlation coefficients $R^{2}=0.854$ (2005-2007) and $R^{2}=0.754$ (1991-2004). Dependence of the onset of budbreak and foliation on the soil temperature is proved by a correlation coefficient $R^{2}=0.658$ (2005 to 2007) and $\mathrm{R}^{2}=0.687$ in the period 1991 to 2004 . Results show that in recent years, the earlier onset of spring phenological stages occurs at the higher sum of effective temperatures. The length of their duration shortens.
\end{abstract}

phenological stages, effective temperature, weather, temperature sum, Norway spruce (Picea abies /L./ Karst.), monoculture, environment

The phenology of forest tree species can be used at the evaluation of the effect of actual conditions of the environment on the development of plant communities and thus, to contribute to the discussed problem of climatic changes, their impacts on the species composition and health conditions of forest ecosystems. Due to warming, changes in the development of forest tree species and herbs can also occur. Therefore, plants can be considered to be bioindicators of climatic changes (Menzel, Dose, 2004; Koch et al., 2005; Škvareninová et al., 2007, 2009a, 2009b). Thus, effects of climatic changes on forest stands are a long-term phenomenon requiring continuous phenological monitoring. The onset and course of particular phenological stages are substantially affected by air temperatures because their effects can accelerate or slow down the growth and development of plants (Larcher, 2003). In addition to air temperature, also the soil temperature and moisture are of decisive effects (Luknárová, 2000; Bednářová, Kučera, 2002; Bednářová, Merklová, 2007). Temperature requirements of trees can be best evaluated by means of sums of effective temperatures (Bagar, Klimánek, 1999; Merklová, Bednářová, 2008; Škvareninová et al., 2007 a, b). 


\section{MATERIAL AND METHODS}

Phenological stages of a pure spruce stand (of the third age class) have been monitored on a research plot of the Institute of Forest Ecology, Mendel University in Brno. The research plot (Rájec Němčice) is situated on a NE to E slope of the Upland range at an altitude of $625 \mathrm{~m}$. The plot is determined by coordinates $16^{\circ} 41^{\prime} 30^{\prime \prime} \mathrm{E}$ and $49^{\circ} 26^{\prime} 31^{\prime \prime} \mathrm{N}$ in the Drahanská Upland geographical unit. Climatically, the region ranks among moderately warm and humid areas with the long-term average of annual temperature $6.6^{\circ} \mathrm{C}$ and $683 \mathrm{~mm}$ annual precipitation (composite authors, 1992). Fig. 1 characterizes the actual temperature and precipitation situation of the locality. of air temperatures $>5{ }^{\circ} \mathrm{C}$ and at soil temperatures values $>1{ }^{\circ} \mathrm{C}$.

The air temperature in a stand was monitored by means of a Datalogger Minikon T sensor placed at the lower margin of crowns. To measure soil temperatures and soil suction potential a MicroLog Sp sensor was used and a gypsum block placed at a depth of $20 \mathrm{~cm}$. The air temperature and global radiation in the open air were measured by means of a Datalogger Minikin RT sensor. To monitor the amount and intensity of precipitation in the open air a Climatronic sensor and a datalogger Microlog ER were installed. The methodology and installation of measurements were described in detain in a paper (Kučera, 2003, 2005).

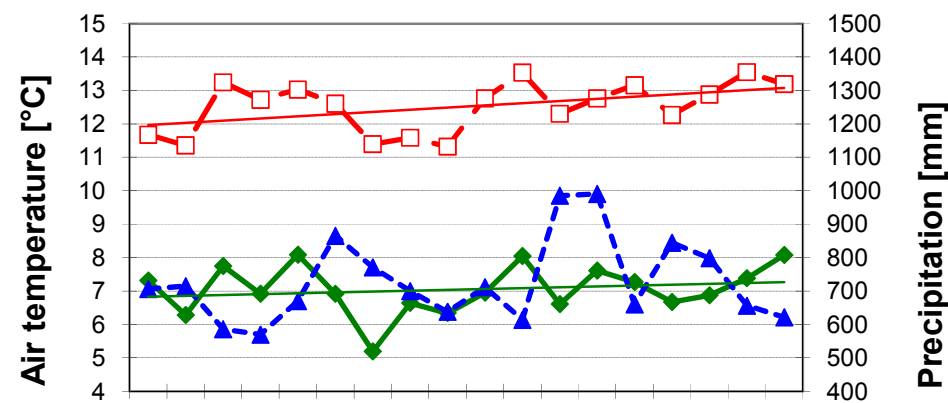



Year

$\longrightarrow$ Average annual air temperature [oC]

$\longrightarrow-$ Average air temperature in the growing season [oC]

$-\rightarrow--$ Annual precipitation $[\mathrm{mm}]$

1: Average annual air temperature and total annual precipitation in 1990 to 2007

Methods of the Czech Hydro-Meteorological Office (ČHMÚ) (1987) were used for phenological monitoring. Phenological and growth stages are monitored at ten selected co-dominant trees of Norway spruce (Picea abies /L./ Karst.) of the same provenance. During the spring period (April to June), phenological monitoring was carried out three-times a week. To the date of a particular phenological stage, an ordinal number of a day from the beginning of a calendar year was attached. Following stages were monitored: budbreak from $10 \%$, the beginning of foliation from $10 \%$, the beginning of foliation from $50 \%$, the beginning of foliation from 100\%, fully unfolded leaf area (100\% foliation). The onset of particular phenological stages was determined on the day when at least 50\% monitored trees reached the given stage. Responses of phenological stages of a monitored species on the environment parameters were evaluated on the basis of sums of cumulative temperatures of air and soil. Evaluation of temperature sums showed that in the region of the Drahanská vrchovina Upland (with cold climate), it was most suitable to use the sum

\section{RESULTS AND DISCUSSION}

A response of the onset and duration of phenological stages on the air temperature at Norway spruce (Picea abies /L./ Karst.) was described by means of cumulative sums of effective temperatures. Larcher (2003) mentions that for the budbreak of trees of a temperate zone daily temperature above $5{ }^{\circ} \mathrm{C}$ are important. The course of air temperatures is closely related to the soil temperature regime. Statistical evaluation of results of a phenological study (Bednářová, Kučera, 2002) showed that the beginning of budbreak and foliation was affected both by air and soil temperatures.

\section{Response of phenological stages on the variability of weather}

Results of the time course of phenological stages in a spruce monoculture in 2005 to 2007 are evident from Fig. 2. Fig. 3 characterizes the onset and duration of phenological stages at Norway spruce on the evaluated plot in 1991 to 2004.

In 2005, the phenological stage of budbreak from $10 \%$ occurred the $124^{\text {th }}$ day from the beginning 


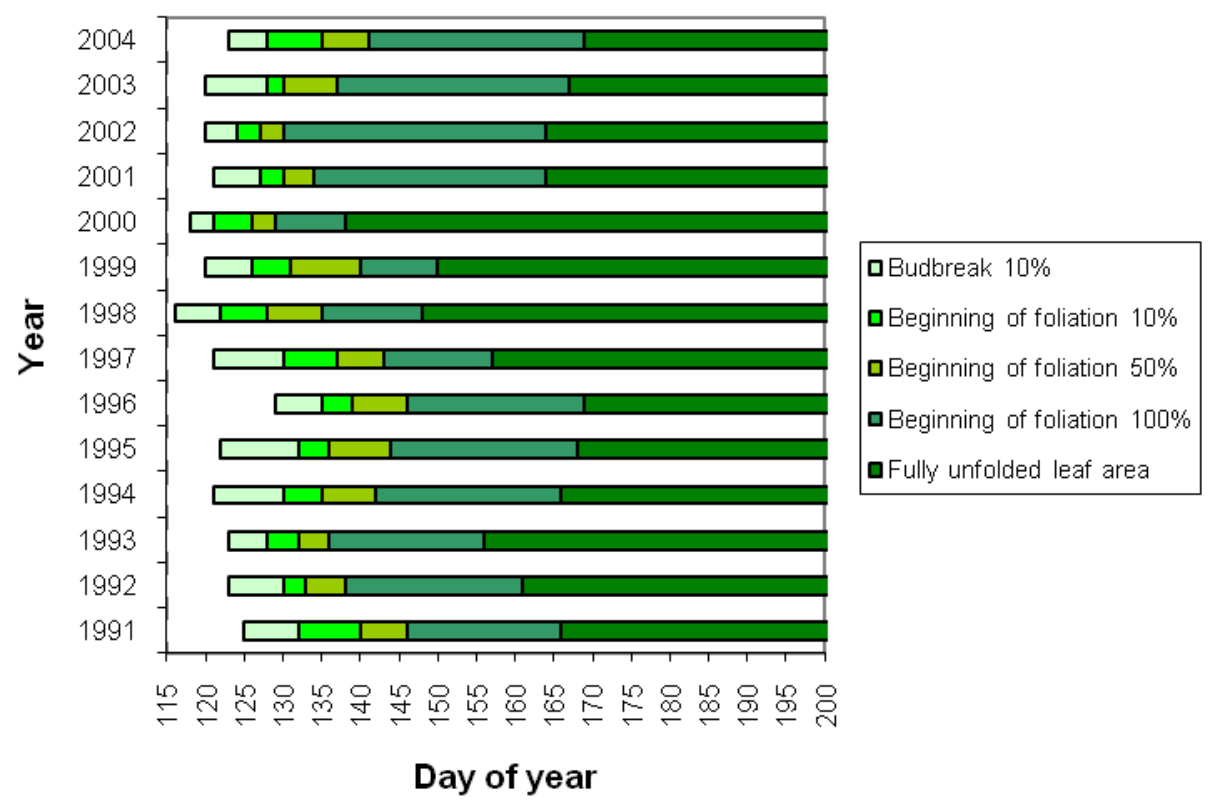

2: Onset and duration of vegetative phenological stages in a sprus monoculture in the year 1991-2004

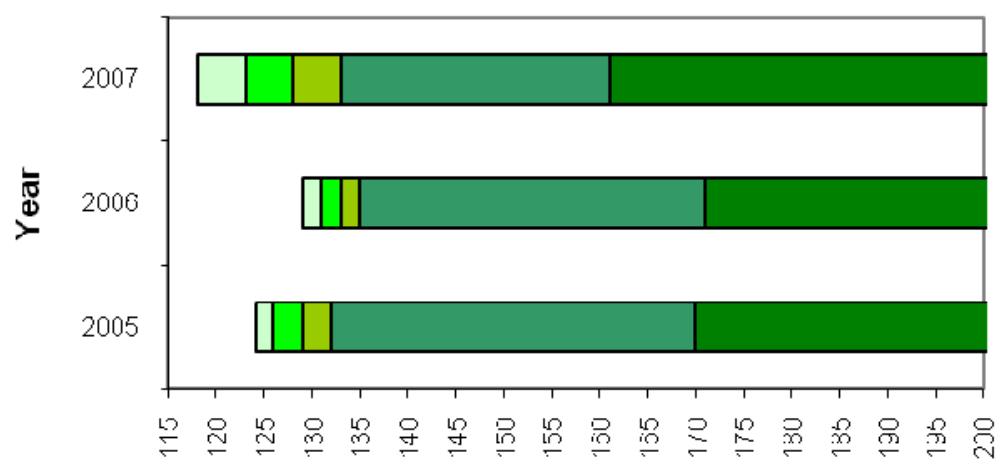

Day of year

\begin{tabular}{|c|c|}
\hline $\begin{array}{l}\text { QBudbreak ' } 0 \% \\
\text { aBeginning of foliation } 50 \% \\
\text { aFully unfolded leaf area }\end{array}$ & $\begin{array}{l}\text { QBeginning of foliation } 10 \% \\
\text { QBeginning of foliation } 100 \%\end{array}$ \\
\hline
\end{tabular}

3: Onset and duration of vegetative phenological stages in a sprus monoculture in the year 2005-2007

of a calendar year, in 2006 the $129^{\text {th }}$ day and in 2007 already in the $118^{\text {th }}$ day. The stage of the beginning of foliation from $10 \%$ was noted the $126^{\text {th }}$ day in 2005 , in 2006 the $131^{\text {st }}$ day and in 2007 the $123^{\text {rd }}$ day. The stage of the beginning of foliation from $50 \%$ began the $130^{\text {th }}$ day in 2005 , in 2006 the $133^{\text {rd }}$ day, in 2007 the $128^{\text {th }}$ day. The beginning of foliation from $100 \%$ was noticeable the $133^{\text {rd }}$ day in 2005 , in 2006 in the $135^{\text {th }}$ day and in 2007 the $132^{\text {nd }}$ day. The full foliation of a spruce monoculture (quite unfolded leaf area) occurred the $171^{\text {st }}$ day from the beginning of the year in 2005 and 2006. In 2007, this stage began 10 days earlier.

The average value of budbreak from $10 \%$ occurred the $122^{\text {nd }}$ day from the beginning of the year in the period 1991 to 2004 (Bednářová, Kučera, 2002; Merklová, Bednářová, 2005). In 2005, this stage occurred 6 days later, in 2006 some 7 days later and in 2007 some 4 days earlier as against a long-term average. The onset of foliation from $10 \%$ occurred the $128^{\text {th }}$ day in 1991-2004. In 2005 by 10 days later as against a long-term average, in 2006 by 3 days later and in 2007 by 5 days earlier owing to high temperatures in the period March to April. The beginning of foliation from $50 \%$ occurred on average (1991-2004) the 133 $3^{\text {rd }}$ day. In 2005, this stage was noted 7 days later. In 2006, the stage of foliation occurred the $133^{\text {rd }}$ day. In 2007, the beginning of the monitored stage was 5 days earlier as against a longterm average. The beginning of 100\% foliation 
occurred on average (1991-2004) the 139th day. In 2005 by 4 days later as against a long-term average, in 2006 some 4 days earlier and in 2007 some 6 days earlier. The highest variation interval for the whole monitored period (1991-2007) showed the phenological stage of full foliation, namely 33 days. In the course of particular years, differences in the onset of phenological stages occurred. Results of our monitoring as well as data of other authors demonstrate that in recent years, the earlier onset of phenological stages occurs, particularly in the spring season (Škvareninivá, 2009 a, b; Bagar, Nekovár, 2007). Results obtained prove that the variability of the onset and duration of phenological stages of forest trees are particularly affected by meteorological factors. As a result of higher temperatures at the beginning of spring, the earlier onset occurs of phenological stages associated with shortening the length of their duration and a shift of the growing season to late autumn. These findings correspond also with results obtained by other authors (Menzel et al., 2003; Scheifinger et al., 2003; Seidel, 2005 and Sparks et al., 2006). The sum of effective temperatures is a decisive characteristic to evaluate the beginning of budbreak and the onset of other phenological stages preceding this stage.

\section{Effects of effective air temperatures on the onset and duration of phenological stages}

The onset of budbreak in the spruce stand occurred on average the $125^{\text {th }}$ day from the beginning of the year at the sum of temperatures TS $5=152.4^{\circ} \mathrm{C}$ in the period 2005-2007. The lowest temperature, when this stage was achieved (in 2005 to 2007), was $\mathrm{TS} 5=135.6^{\circ} \mathrm{C}$ and the highest temperature TS5 $=$ $164.5^{\circ} \mathrm{C}$. In the monitored period 1991 to 2004 , the average temperature for the beginning of budbreak was TS $5=132.4^{\circ} \mathrm{C}$. The beginning of $10 \%$ foliation was on average (2005 to 2007) affected by the sum of effective temperatures TS $5=168.7^{\circ} \mathrm{C}$, at maximum $176.6^{\circ} \mathrm{C}$ and minimum $156.9^{\circ} \mathrm{C}$. In the period 1991 to 2004 , a value to achieve this stage was on average TS5 $=180.7^{\circ} \mathrm{C}$. In 2005-2007, the phenological stage "the onset of $50 \%$ foliation" was conditioned by the average temperature of TS5 $=185.0{ }^{\circ} \mathrm{C}$, at maximum $189.1{ }^{\circ} \mathrm{C}$ and minimum $179.6{ }^{\circ} \mathrm{C}$. In 1991-2004, the sum of effective temperatures for this stage was on average $209.7^{\circ} \mathrm{C}$. In the period 2005-2007, the beginning of 100\% foliation was at $\mathrm{TS} 5=200.6{ }^{\circ} \mathrm{C}$ (minimum $179.6{ }^{\circ} \mathrm{C}$ and maximum $\left.217.6^{\circ} \mathrm{C}\right)$. In a long-term average (1991-2004), this stage was conditioned by a temperature $264.6^{\circ} \mathrm{C}$. The full unfoldment of leaf area occurred in 2005 2007 when the sum of effective temperatures reached on average $494.8^{\circ} \mathrm{C}$ at maximum $502.1{ }^{\circ} \mathrm{C}$ and minimum $482.1{ }^{\circ} \mathrm{C}$. In a long-term average (1991-2004), this stage occurred at a temperature of TS5 $=464.0$. High dependence between the onset of phenological stages and air temperatures in the period before the beginning of the monitored stage is proved by statistically significant correlation coefficients. At the budbreak of spruce $\mathrm{R}^{2}=0.854$ $(p=0.075)$. The determined dependences agree with data of other authors. Bednářová and Kučera (2002) found also dependence of the onset of budbreak of Norway spruce on the sum of effective temperatures of spruce $\left(\mathrm{R}^{2}=0.754\right)$. Also Luknárová (2001), Braslavská and Kamenský (1999) mention high correlation between the onset of the stage of budbreak at Norway spruce and air temperatures.

\section{Effects of soil temperatures on the onset and duration of phenological stages}

The soil temperature regime is closely connected with the development of air temperature. To determine the rate of dependence of these two main microclimatic factors in the monitored stand linear regression was carried out between the air temperature and soil temperature. The rate of variability between the soil temperature and air temperature amounted to $\mathrm{R}^{2}=0.864$. Results of a long-term phenological study (Bednářová, Kučera, 2002) showed that the budbreak of Norway spruce was considerably affected by soil temperature $\left(\mathrm{R}^{2}\right.$ $=0.69$ ). This finding is also confirmed by results obtained in the period 2005 to 2007. At temperature sums $>1{ }^{\circ} \mathrm{C}$, dependence was found on soil temperature $\mathrm{R}^{2}=0.65$. Results obtained show that also the temperature of soil considerably affects the budbreak and the onset of foliation of spruce. Lawander et al. (1973), Timmis and Worral (1974) came to the same conclusion. They mention in their papers that the temperature of soil shows considerable role in the phenology of budbreak. Particular factors affecting budbreak cannot be separated (isolated) and thus, it is necessary to evaluate them as a whole complex.

\section{CONCLUSIONS}

The beginning and duration of phenological stages change according to the character of weather in particular years. Evaluated phenological studies in the spruce monoculture for the period 2005 to 2007 are compared with long-term results from 1991 to 2004. Results obtained show that in addition to genetic factors, the onset and duration of particular phenological stages are particularly affected by air and soil temperatures before the onset of a respective phenological stage. These decisive stages cannot be separated from each other and it is necessary to evaluate them as a whole. In comparison with a long-term study we can see that in recent years, the earlier onset of spring phenological stages occurs and their duration shortens. In the period 2005 to 2007 , the range of the budbreak phenological stage (10\%) took 11 days, at the stage "beginning of foliation" from $10 \%$ was 8 days, the stage "beginning of foliation" from $50 \%$ took 5 days and the beginning of foliation from $100 \%$ was in the range of 3 days. Full foliation in the period 2005 to 2007 was in the range of 10 days. The year 2007 was very atypical. The onset of spring phenological stages occurred first of all in the whole 
17-year period of monitoring. At the evaluation of phenological stages for the period 1991 to 2004 we can note that the highest extent between particular years occurred at the stage "full foliation" (31 days) and at the stage "the beginning of foliation" from 100\% (17 days). If we evaluate the whole period of monitoring in this locality (1991-2007) we can see that the extent of the budbreak onset was 13 days, that of the foliation onset from 50\% some 14 days, the beginning of foliation from 100\% 17 days and the extent of the full foliation 33 days. The onset and duration of spring phenological stages on the monitored area are particularly dependent on the temperature of air and soil because this area is not endangered by the critical lack of precipitation in the spring season. High dependences were found out between the sum of effective air temperatures $\left(>5^{\circ} \mathrm{C}\right)$ and the budbreak of Norway spruce. High dependences were also proved of the onset of spring phenological stages on the sum of soil temperatures higher than $1{ }^{\circ} \mathrm{C}$. The stage of $10 \%$ budbreak in the period 2005-2007 at the sum of air temperatures $152.4^{\circ} \mathrm{C}$ and in the period $1991-2004$ at the sum of $132.4^{\circ} \mathrm{C}$. Full foliation occurred in 2005-2007 at the sum of air temperatures $494 .{ }^{\circ} \mathrm{C}$. In the period $1991-$ 2004 , this stage was conditioned by the sum of 464.0 ${ }^{\circ} \mathrm{C}$. It follows that the onset of spring phenological stages occurs in an earlier period at the higher sum of temperatures and the length of their duration shortens. Phenological studies can serve as the bioindicator of climatic changes.

\section{SUMMARY}

The aim of the paper was to evaluate the onset and duration of vegetative stages of Norway spruce (Picea abies /L./ Karst.) in a spruce monoculture of the third age class depending on parameters of the environment. Results obtained for the period 2005 to 2007 were compared with the monitored phenology in this stand for the period 1991 to 2004. The evaluated stand is situated at an altitude of $625 \mathrm{~m}$ in the Drahanská vrchovina Upland. During the 17-year period, following phenological stages were evaluated: the onset of $10 \%$ budbreak, the onset of $10 \%$ foliation, the onset of $50 \%$ foliation, the onset of $100 \%$ foliation and fully unfolded leaf area (full 100\% foliation). Temperature requirements for the onset of particular phenological stage at Norway spruce were evaluated on the basis of cumulative sums of effective temperatures of air and soil. Evaluation of temperature sums in relation to phenological stages showed that in the region of the Drahanská vrchovin Upland (area with colder climate) it was most suitable to use values exceeding $5{ }^{\circ} \mathrm{C}$ for the sum of effective air temperatures and values exceeding $1{ }^{\circ} \mathrm{C}$ for the sum of soil temperatures. Results obtained show that in addition to genetic factors the onset and duration of particular phenological stages are significantly affected by air and soil temperatures before the onset of a respective phenological stage. These decisive factors cannot be separated from each other and have to be evaluated as a complex. Through linear regression, the rate of variability was determined between the temperature of soil and the temperature of air, namely $\mathrm{R}^{2}=0.864$. High dependence between the onset of budbreak at Norway spruce and air temperature is proved by statistically significant correlation coefficients $\mathrm{R}^{2}=0.854$ for the period $2005-2007$. In the period 1991 to 2004, correlation coefficient $\mathrm{R}^{2}=0.754$ was proved. The dependence of budbreak and the beginning of foliation on the temperature of soil is proved by a correlation coefficient $\mathrm{R}^{2}=0.658$ in 2005 to 2007. In 1991 to 2004, the value of a correlation coefficient for this parameter was $\mathrm{R}^{2}=0.687$. Onsets and duration of phenological stages differed in particular years due to different climatic conditions. During the whole monitoring, an extent was determined in the onset of the phenological stage of the beginning of budbreak, namely 13 days, for the stage "the beginning of 50\% foliation" 14 days and for the stage "fully unfolded leaf area" 33 days. The 17-year monitoring of phenological stages in a spruce monoculture show that in recent years, the earlier onset of phenological stages occurs at higher sums of effective temperatures and the duration of particular phenological stages shortens. Even in autumn months, higher sums of effective temperatures were noted. Thus, lengthening the growing season occurs at the expense of the period of rest. However, from the long-term aspect, this phenomenon can have negative effects on the health condition of forest stands.

\section{Acknowledgements}

This paper was supported by the Ministry of Education, Youth and Sports of the Czech Republic, project No. MSM 6215648902 and the Czech Terra SP/2dl/93/07 project.

\section{REFERENCES}

BAGAR, R., KLIMÁNEK, M., 1999: Vyhodnocení fenologického pozorování z lokality Hrušovany $\mathrm{u}$ Brna. Acta Universitatis et silicultuare Mendeliane Brunensis, 47/3: 45-56.
BAGAR, R., NEKOVÁŘ, J., 2007: Porovnání růstových podmínek v I.-IV. lesním vegetačním stupni. In: International Scientific Conference Bioclimatology and natucal hazards proceedings. Slovenská bioklimatologická společnost a TU 
ve Zvolenu. Polana nad Detvou (SK), September 17-20, 2007, s. 1-7.

BEDNÁŘOVÁ, E., KUČERA, J., 2002: Phenological observations of two spruce stands (Picea abies /L./ Karst.) of different age in the years 1991-2000. Ekológia (Bratislava), Vol. 21, Supplement 1/2002, p. 98-106.

BEDNÁŘOVÁ, E., MERKLOVÁ, L., 2007: Results of monitoring the vegetative phenological phases of European beech (Fagus sylvatica L.) in 1991-2006. Folia Oecologica, 34/2: 77-85.

BRASLAVSKĀ, O., KAMENSKÝ, L., 1999: Fenologické charakteristiky ihličnatých drevin na Slovensku v období 1986-1995. Meteorology Journal, SHMÚ, Bratislava 2/3: 41-47.

COMPOSITE AUTHORS, 1992: Ekologické důsledky obnovy smrkových porostů holosečným způsobem. Kontrolovatelná etapa výzkumného úkolu. MZLU v Brně, ÚEL, 120 s.

ČHMÚ, 1997: Návod pro činnost meteorologických stanic - Lesní rostliny. Metodický predpis č. 10. Praha ČHMÚ, $111 \mathrm{~s}$.

KOCH, E., BRUNS, E., CHMIELEWSKI, F., DEFILA, C., LIPA, W., MENZEL, A., 2005: Guidelines for plant phenological observations. Zentralanstalt für Meteorologie und Geodynamik, Austria, Deutscher Wetterdienst, Germany, HU Berlin, Germany, Meteo-Swiss, Schwitzerland, TU München, Germany, 39 p.

KUČERA, J., 2003: Minikin - Dataloger with embedded sensors - smart sensors. User's Manual, Brno, www.emsbrno.cz, 8 p.

KUČERA, J., 2005: MicroLog SP - One-channel datalogger for soil water potential measurement. User's manual, Brno, www.emsbrno.cz, 9 p.

LARCHER, W., 2003: Physiological Plant Ecology. Springer-Verlag Berlin, Heidelberg, 513 p.

LAWANDER, D. P., SWEEN, G. B., ZABR, J. B., 1973: Spring shoot growth in Douglas-fir may be initiated by giberlins exported from the roots. Science, 182, p. 838-839.

LUKNÁROVĀ, V., 2000: Fenologické pozorovanie smreka obyčajného a zmeny klímy. Enviromagazin, 5/5: 14-15.

LUKNÁROVÁ, V., 2001: Dependence of the the onset of spring phenological phases Of Norway spruce on climatic elements. Meteorological Journal, SHMÚ, Bratislava, 4/2: 29-37.

MERKLOVÁ, L., BEDNÁŘOVÁ, E., 2005: Vliv mikroklimatu stanoviště na nástup a průběh jarních fenologických fází u smrku ztepilého a buku lesního. In: Sborník příspěvků z mezinárodní mezinárodní vědecké konference Bioklimatologie sučasnosti a budoucnost., ČSBS Praha, MZLU v Brně, TU Zvolen, SPU Nitra. Křtiny 8.11. 9. 2005. s. 2-8.

MERKLOVÁ, L., BEDNÁŘOVÁ, E., 2008: Results of a phenological study of the tree layer of mixed stand in the region of the Drahanská vrchovina Upland. Journal of Forest Science, 54, (7): 294-305.

MENZEL, A., JAKOBI, G, AHAS, R., SCHREIFINGER, H., ESTRELLA, N., 2003: Variations of the climatological growing season (1951-2000) in Germany compared with other countries. Journal of Climatology, 23: 793-812.

MENZEL, A., DOSE, V., 2004: Phenologie als Klimaindikator - neue Methoden. Forstliche Meteorologie und Hydrologie, II: 54-58.

SCHEIFINGER, H., MANZEL, A., KOCH, E., PETER, C., 2003: Trends of spring time forest events and phenological dates in Central Europe. Theor. Appl. Climatol. 74: 41-51.

SEIDEL, R., 2005: Witterung und Pflanzenentwicklung im Winter 2004/2005. Phänologie - Journal, 24: $1-2$.

SPARKS, T. H., HUBER, K., CROXTON, P. J., 2006: Plant development scores from fixed-date photographs: the influence of weather variables and recorder experience. International Journal of Biometeorology, 50 (5): 275-279.

ŠKVARENINOVÁ, J., BEDNÁŘOVÁ, E., MERKLOVÁ, L., 2007: Vyhodnotenie jarnych fenologických fenofáz hlohu obyčajného (Crataegus oxyancantha L.) na Drahanskej vrchovine a Zvolenskej kotline. In: International Scientific Conference Bioclimatology and natural hazards - procedings. TU Zvolen (SK), Slovenská bioklimatologická spoločnost. Polana nad Detvou 5.-8. 9. 2007.s. 1-9.

ŠKVARENINOVÁ, J., 2009a: Priebeh vegetatívnych fenologickych fáz autochtónnych populacií smreka obyčajného (Picea abies /L./ Karst) zo Slovenska. Forestry Journal, 55 (1): 13-27.

ŠKVARENINOVÁ, J., 2009b: Nástup vegetatívnych fenologickych fáz populácií smreka obyčajného (Picea abies /L./ Karst.) zo Slovenska vo vztahu k teplotnym sumám. Meteorological Journal, 12/ (23): 109-113.

TIMMIS, T., WORRAL, J., 1974: Translocation of dehardening and bud-break promoters in climatically split Douglas-fir. Can. J. For. Res., 4: 229-237. 